\title{
Towards sustainable Latin American agglomerations
}

\author{
I. M. Madaleno \\ Portuguese Tropical Research Institute, Portugal
}

\begin{abstract}
The paper presents a comparative study carried out over the course of a decade and a half in ten Latin American cities and metropolitan regions: Lima (Peru), Santiago and Iquique (Chile), Río Cuarto (Argentina), Colonia del Sacramento (Uruguay), Belen and S. Louis (Brazil), Havana (Cuba), San José (Costa Rica) and Mexico City (Mexico). The objectives of the study are twofold: to report successes in natural resources management at a local level as paradoxes of globalisation and to publicise how cultivated front and backyards contribute to build more sustainable urban agglomerations, benefitting both the society and the environment, because traditional healing practices and ethno-botanical knowledge are important legacies for future generations. The sources of data were a sample of one thousand, two hundred and fifty-four inquiries, $70 \%$ of which were urban gardeners and periurban farmers. Qualitative research included video records of particular interviewed traditional healers and urban gardeners, sometimes together with their flourishing plots. The investigated plant species have been photographed so as to permit easier dissemination of results to the scientific community and to the general public. Results have confirmed that native species and ancient indigenous prescriptions dominate, with the exceptions of Cuba and Argentina where native ethnic groups have been eradicated, and Uruguay, where the European influence was stronger. Gardening and periurban farming are beneficial for the social, cultural, economic and environmental sustainability of cities and metropolitan regions.

Keywords: sustainable Latin American cities, medicinal plants.
\end{abstract}

\section{Introduction}

In spite of the risks and uncertainty in growing food, such as climate change, bad weather, pest-induced crop losses, a considerable proportion of city residents 
invest their time and meagre resources in fresh produce [1]. Food is not the only purpose of urban agriculture, as we have learnt in Brazil [2, 3]. Urban gardeners grow lettuce together with spices and medicinal herbs, using their front and backyards, peri-urban vacant plots and community gardens. The intercropping of species helps to eradicate undesirable insects and creates micro-climates whilst augmenting moisture and facilitating rainwater permeation. In the home gardens there is seldom mono-cultivation; fruit culture is intertwined with annual plants, and the plot fertilisation is usually organic, both because it is cheaper and for the reason that local food is widely perceived as a healthier choice than the chemically driven food industry available in retail stores [1]. Garden irrigation uses wells or municipal water supply $[4,5]$.

Organic agriculture is "a production system that sustains the health of soils, ecosystems and people. It relies on ecological processes, biodiversity and cycles adapted to local conditions, rather than the use of inputs with adverse effects. Organic agriculture combines tradition, innovation and science in order to benefit the shared environment, and promote fair relationships as well as a good quality of life for all involved" [6]. Present research was initiated in Belen, Brazil, in 1998, with an urban agriculture project. Because of the high proportion of medicinal plants gardened in front and backyards, the Portuguese Tropical Research Institute (IICT) decided to expand the fieldwork to other Latin American cities and metropolitan areas, in order to examine organic cultivation in the urban realm.

The aim of the project was to undertake ethno-botanical and ethno-geographic studies designed to evaluate the consumption of plant species in cities of Latin America, both by less wealthy populations and plant therapy believers, because the health of individuals and communities cannot be separated from the health of the urban ecosystems [6, 7]. The research hypotheses were twofold: 1) The preservation of garden biodiversity contributes for a healthy urban environment, which includes plant species used in domestic therapies, in popular medicine; 2) Native and exotic species are valuable resources and important legacies for future generations, still in use today, because they constitute less expensive alternatives for the poor residents in the urban realm.

\section{Methods}

Surveys conducted in eight countries located in Latin America, comprised five in South America (Brazil, Peru, Chile, Argentina, Uruguay), two small countries from Central America and the Caribbean (Costa Rica and Cuba), and the North American part of Mexico. In Costa Rica and in Uruguay the research was not carried out in partnership with local universities. The design and the active participation of colleagues from partner research institutions were possible in the remainder: In Brazil, with the Federal University of Para state and Emilio Goeldi Museum [8]; in Peru with the Pontifical University of Lima; in Chile with the National University of Chile, in Santiago and the Arturo Prat University, in Iquique [9]; in Argentina, the survey was conducted in partnership with Rio 
Cuarto University, in Cordoba [10]; in Cuba with the University of Havana; in Mexico with the Autonomous National University of Mexico [7].

The cities and metropolitan regions varied from the country capital and surrounding areas (i.e. Mexico City and part of the wide Central Metropolis, comprising Puebla and Cuernavaca), state capitals (Belen and S. Louis, in Brazil), and smaller cities (Iquique, Rio Cuarto, Colonia del Sacramento). These were chosen for being both in a representative geographical location (desert areas, the pampas, and the River Plate shore) and because of their cultural background (Andean Aymara Indians city, the first one, and two remote Franciscan and Jesuit missions, the last two countries).

Fieldwork involved the investigation of historical data, in local archives and libraries, and in Europe. The bulk of the research was, however, composed by surveys of the medicinal flora and associated practises, using a sample questionnaire that targeted mainly 3 types of informants: 1) Urban gardeners and farmers (70\% of the interviewed); 2) Herb traders (25.7\%); 3) traditional healers, wild species collectors and consumers (3.6\%). Table 1 displays information about all surveys per city or metropolitan region.

Table 1: $\quad$ Surveys conducted in six Latin American metropolises and four cities.

\begin{tabular}{|c|c|c|c|c|}
\hline $\begin{array}{l}\text { Metropolitan Regions } \\
\text { (MR) and Cities }\end{array}$ & $\begin{array}{l}\text { Samples } \\
\text { (n.) }\end{array}$ & $\begin{array}{l}\text { Urban gardeners } \\
\text { and farmers }(\%)\end{array}$ & $\begin{array}{c}\text { Herb traders } \\
(\%)\end{array}$ & $\begin{array}{c}\text { Healers, wild species } \\
\text { collectors and } \\
\text { consumers (\%) }\end{array}$ \\
\hline MR of Belen, Brazil & 570 & 97.3 & 2.3 & 0.4 \\
\hline MR of Santiago, Chile & 132 & 84.1 & 15.1 & 0.8 \\
\hline $\begin{array}{l}\text { MR of Central Mexico, } \\
\text { Mexico }\end{array}$ & 100 & 42.0 & 48.0 & 10.0 \\
\hline MR of Lima, Peru & 34 & 0.0 & 88.2 & 11.8 \\
\hline MR of Havana, Cuba & 50 & 94.0 & 6.0 & 0.0 \\
\hline $\begin{array}{l}\text { MR of San Jose, Costa } \\
\text { Rica }\end{array}$ & 43 & 69.7 & 28.0 & 2.3 \\
\hline S. Luis, Brazil & 100 & 90.0 & 8.0 & 2.0 \\
\hline Río Cuarto, Argentina & 100 & 80.0 & 17.0 & 3.0 \\
\hline $\begin{array}{l}\text { Colonia del Sacramento, } \\
\text { Uruguay }\end{array}$ & 50 & 48.0 & 14.0 & 38.0 \\
\hline Iquique, Chile & 75 & 64.0 & 30.7 & 5.3 \\
\hline Total or average & 1,254 & 70.0 & 25.7 & 3.6 \\
\hline
\end{tabular}

Source: author surveys (Chile: Madaleno and Gurovich, Santiago; Madaleno and Delatorre-Herrera, Iquique; Argentina: Madaleno and Montero; Mexico: Madaleno and Sanchez, Cuernavaca).

\section{Results and discussion}

Sustainable cities are widely perceived as places where economic, social and environmental needs are met. The notion is based both on the conceptualization 
of sustainable development, such as it has been conceived by the World Commission on Environment and Development [11], and on the ecosystem approach [12]. Climate change has produced a considerable number of natural catastrophes that are increasingly targeting the urban realm, and particularly coastal regions. The risks posed by the rising sea water level and the uncertainties of the weather have given way to new paths in urban planning and management, with the introduction of resilient cities frameworks [13]. Nevertheless, Dawley, Pike and Tomaney argue that the equilibrium-based approach of resilience is incorrect. The ability of a city or a region to go back to the previous state has proven practically impossible, both in case of natural catastrophes and after economic crisis [14-16].

What comes to my mind when trying to perceive an urban centre that has been destroyed by a cataclysm is that of ancient Pompeii. Was it possible then to recover from such destructive volcanic eruption? No. With our technological advances, would we make, nowadays, any city resilient enough to return to the pre-shock situation? Hardly! As to the second cause for disaster, is it possible to recover from a crisis that has short duration? It most probably is. Was it possible to go back to the previous state of wealth after the Great Depression? It took decades and most lost the possibility to have a normal living income forever.

Let us concentrate on small problems, as compared to the extreme ones presented. Cities and regions are different as diverse is the scale of catastrophes. Under this assumption, in a world where climate change is posing new challenges, the future of cities depends on the ability to produce food and health within urban limits, vis a vis medieval castles that had a planned capacity to provide fruits and vegetables, as well as medicinal species, to the residents, an inventive solution for the eventuality of being under siege for prolonged times. Food sensitive urban design is now seen as a wise contribution to the sustainability of cities, whereas it facilitates equitable access to healthy food [14].

Many programs have been designed to promote gardening, even among aboriginal communities [17], based on the (pre)concept that ancient ways of perceiving nature as part of Amerindians' culture have been lost. It is not the case with current research approach. Once the starting posture was not one of trying to impose Western traditions and culture, we realized that most Indians and Mestizos interviewed continue transmitting traditional medicinal knowledge inside the family. It is true, though, as Mirella Stroink and Connie Nelson acknowledged among aboriginal communities in Canada, that, on the whole, the old ways to cultivate a garden are less organised, less manipulative of nature, and more spontaneous than the Western scientific ways to grow food and medicinal herbs [17]. Indigenous populations are also more prone to grow organic vegetables, not only because they consider them healthier but also for being cheaper, as said [18].

\subsection{The first result}

Therefore, as the first result, it is important to highlight that only $8 \%$ of the urban gardeners and periurban farmers sample researched in Latin America used 
chemical fertilizers. Pesticides application was rare whilst the intertwining of insect repellent species, such as Cimbopogon citratus, was promoted by extension services [10]. Havana metropolitan region, in Cuba [19], registered the highest organic fertilizer input (97.8\%), and Santiago, in Chile [20], the lowest (76\%).

This way, the economic activity under investigation, meaning, urban agriculture, doesn't contribute to the pollution and degradation of land and water resources, as other economic activities might. Whilst the increasing concrete constructions (tall buildings) and the impermeable surfaces (roads, paths, tubes, tunnels) existent in urban agglomerations constitute barriers that reroute rivers and water flows; the home gardens, the vacant urban plot farms, the legal or illegal farms existent along highways and roads, the periurban farms, sustain the water cycle, regulate temperatures and thus decrease the greenhouse effect over cities and metropolitan regions [2, 3, 10, 21-24].

Moreover gardens and periurban farms are spaces that produce oxygen, decreasing pollution in urban areas; the consumption of local food further diminishes the necessity to import fresh vegetables from long distances (rural areas inside the country or the importation of food from abroad), and thus decreases the carbon emissions associated with the traffic of trucks, airplanes and big container ships [1]. Organic food and medicinal plant consumption improve the health of the less wealthy urban residents; the ones that lack access to expensive health care systems and pharmaceutical products [7, 19, 24].

\subsection{The second result}

The second result is that, with the exception of Iquique, located in Northern Chile, in nine Latin American cities and metropolitan regions residents gardened and consumed mostly sedative plants (Mexican balm, Chamomile, European balm, Wild lemon bush, Cuban tilo) or a strong stimulant (Mate tea). The stress that is associated to life in urban environments, and particularly in large urban agglomerations such as Mexico City explains the preference. Examples are: 1) an interviewed Mexican herb trader that consumed, on a daily basis, the infusion of two toronjil (Fig. 1) varieties (red and white flower) in order to cope with her daily duties [25]; 2) a Brazilian lottery seller that couldn't go out without her herbal tea [2], including both erva-cidreira (Lippia alba) and carmelitana (Lippia citriodora).

Let us concentrate on the exception in calming potions, Iquique: Aloe vera and barbadensis were the most gardened species in the Chilean capital of the Aymara Indians because of the desert coastal climate dominant there and also because of the renowned therapeutic value of the plant [7,9]. The economic and environmental sustainability of the city dictates the preference for species that mature with scarce irrigation. In desert areas, gardening is hardly affordable for urban residents, because the price of such a meagre commodity as water is quite high. For a similar reason urban gardeners were not interviewed in Lima, Peru, that has the same climate constrictions. Figures 1 to 4 are photos that illustrate the four native American herbs recorded as the top ranking plant species in six of the ten cities surveyed between 1998 and 2012 [5, 18, 25]. 


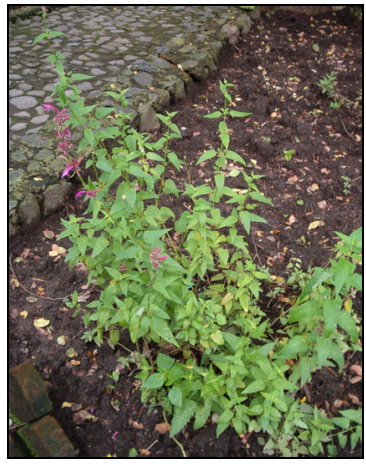

Figure 1: $\quad$ Mexican Balm (Agastache mexicana).

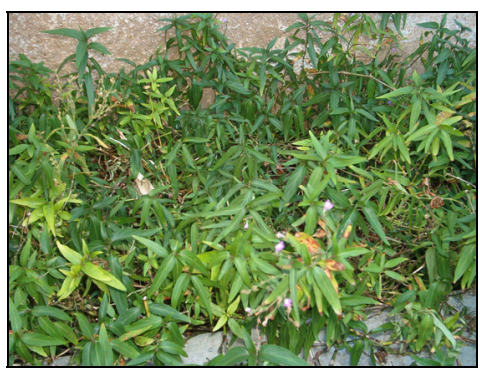

Figure 3: Cuban Tilo (Justicia pectoralis).

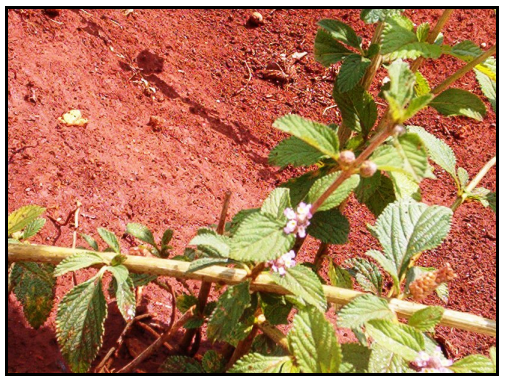

Figure 2: Wild Lemon Bush (Lippia alba).

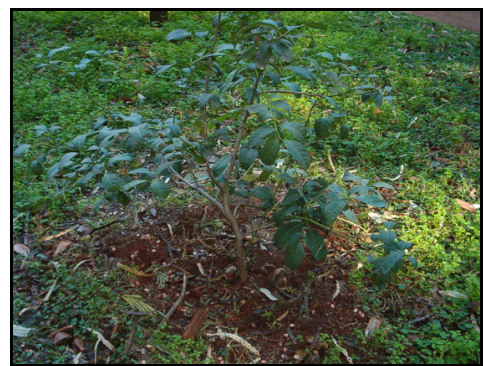

Figure 4: Mate Tea paraguariensis).

\subsection{The third result}

The third result is that the amount and diversity of the vegetable species gardened, traded and recommended is increasing. In fact, if the ecological richness of the Amazon rainforest explains the number of ninety-seven (97) vegetable species gardened in Belen, during two IICT scientific missions to the Amazon region, in 1998 [2]; it falls short when one recalls the number of medicinal plants recorded in the same city during the third mission, in 2005, that only targeted the herb markets and traditional healers: just forty-three (43) species more [5, 7, 18, 25].

In 2004 and 2006, two scientific missions to the Central Mexican Metropolis only accounted for seventy (70) vegetable species used for therapeutic purposes investigated in home gardens, periurban farms, medicinal herb markets, herb collectors and traditional healers [25]. In 2006, a number of sixty (60) plant species were recollected in one survey conducted to the trade markets of medicinal flora rich Peruvian Lima [5, 7, 18].

By contrast, in early 2011, during a joint Portuguese-Argentinean survey carried out in Rio Cuarto, the garden biodiversity included forty plant (40) 
species, and the traded herbs and healers recommendations added up to one hundred and twenty-five species (125), an impressive number as compared to the 140 counted in the Amazonian municipality of Belen, in 1998 and 2005. In 2012, the Iquique survey added 85 plant species [9]. Overall, eight hundred and fortynine medicinal taxa (849) were consumed in ten urban locations and metropolitan regions, two-hundred seventy-two (272) of which were common to more than one country.

I argue that we are a long way from the first study on urban agriculture (UA), when UA was perceived as a solution to tackle poverty in the cities of developing countries [21, 22]. The next phase was to envision UA as a good opportunity for developed countries citizens to grow healthy food [23]. In 2001 Robert Pederson and Aileen Robertson wrote: "Confidence has suffered due to reports about antibiotic resistance, mad cow disease (BSE) and dioxin scares. Many of the food-borne diseases are associated with mass-produced food" [23: 9]. Local food and organic production were considered, then, good solutions for citizens worried about the health risks posed by genetically modified food and chemical safety.

In this second phase, both food security and city greenery [26-28], using among others the input of community forest organisations [26], were the main concerns in urban planning. However, medicinal plant species gardened inside cities and even in periurban farms were not the focus. Plants with therapeutic value are still usually researched by ethno-pharmacy, pharmacognosy and medicine scientists, and published in the vast panoply of related journals [29]. Therapeutic gardens are rarely mentioned in urban agriculture literature [30].

A third phase in the evolution of UA research was initiated by the midst of the first decade of the $21^{\text {st }}$ century. The issue is now the compelling necessity to give self-reliance to citizens affected by climate change [4, 13, 31], and more recently to people impoverished by the great recession [32, 33]. From the purpose of building cities with life quality we were sent back to the basic level of self-sufficiency and to the anti-poverty driven programmes. In social and economic terms we returned to the poverty and insecurity of the mid-1800, when allotment gardens of Europe were created, during the grim days of the Industrial Revolution [30].

\subsection{The fourth result}

The fourth result of data gathered in ten urban agglomerations of eight Latin American countries is that medicinal flora consumed is incredibly diverse. The five hundred and seventy-seven plant species (577), which origin is displayed in Table 2, are predominantly native American. Uruguay was the sole country where European taxa overcame local medicinal flora [34]. In spite of the long territorial disputes between Portugal and Spain, in colonial times, when both claimed the River Plate shore city of Colonia del Sacramento, the European influence on medicinal flora consumption as in architecture endured.

Even there, the preference goes to the stimulant Ilex paraguariensis (Fig. 4), an American herb that in the Southern Atlantic seashores of South America was valued enough to become a trade coin, as seventeen century Jesuit manuscripts 
Table 2: Medicinal plants origin in ten urban agglomerations of Latin America.

\begin{tabular}{|l|c|c|}
\hline \multicolumn{1}{|c|}{ Origin } & Number of Species & (\%) \\
\hline American & 354 & 61.4 \\
\hline European & 76 & 13.1 \\
\hline Asian & 63 & 10.9 \\
\hline African & 12 & 2.1 \\
\hline Pacific & 4 & 0.7 \\
\hline Australian & 7 & 1.2 \\
\hline Universal & 15 & 2.6 \\
\hline Unidentified & 46 & 8.0 \\
\hline Total & 577 & 100 \\
\hline
\end{tabular}

Source: fieldwork data obtained during the 1998-2012 scientific missions.

teach us [35]. The same was valid for Erythroxylum coca on the Pacific coast and to the so much appreciated Theobroma cacao, in Mexico, according to another Jesuit essayist, who wrote a series of books about the Natural History of the Americas, in the fifteenth century [36]. Cocoa paste was ingested by the Aztecs against flu, catarrh and stomach pains. Albeit they were successes on a local scale, in pre-Colombian times, they are now globalised.

The diversity of therapeutic species gardened in tiny gardens or small periurban farms, adds to the biodiversity of flora and associated fauna (i.e. bees, butterflies, birds) in the urban realm. Besides obvious beautification reasons, front and backyard gardening is beneficial to preserve local taxa, as the IICT surveys found that forty-six plants collected were unknown to botanists consulted during the missions. Gardens possess inestimable genetic resources, and the households tend to preserve that capital together with cultural knowledge about their uses.

\subsection{The fifth result}

During the decade and a half the research process took, the IICT found several concrete examples of successful public programmes aimed at urban cultivation, mostly targeting the less wealthy residents. A handful of those initiatives have been published in Spanish, in the aftermath of an urban geography conference that was jointly organised by Spanish and Portuguese universities, in 2012 [38]. Table 3 displays the summary of the action plan observed from 1998 to 2012, in five of the investigated countries. The results encourage further investment in UA. Additionally, it should be emphasised that other remarkable experiences have been reported by the International network of Resource centres on Urban Agriculture and Food security (RUAF), in Peru, coordinated by the Urban Harvest [39]; and in Uruguay [32, 40], allied to the Food and Agriculture Organization (FAO) and the national government. 
Table 3: $\quad$ Urban Agriculture Promotion in Latin America.

\begin{tabular}{|l|c|c|l|}
\hline \multicolumn{1}{|c|}{ Organisations } & Countries & Year & \multicolumn{1}{c|}{ Action Plan } \\
\hline Central government & Cuba & 2009 & Support to organic farming in Havana \\
\hline Central government & Argentina & 2011 & $\begin{array}{l}\text { Seeds distribution, solar energy herb driers, } \\
\text { natural insecticides small producer fairs in } \\
\text { Río Cuarto, Pampa de Córdoba }\end{array}$ \\
\hline Municipality & Chile & 2003 & $\begin{array}{l}\text { Seeds distribution, composting tanks, } \\
\text { ringworms. Organic cultivation training } \\
\text { courses, in La Pintana. }\end{array}$ \\
\hline Water communities & Chile & 2012 & $\begin{array}{l}\text { Organic cultivation and hydroponics } \\
\text { courses. Community management of Maipo } \\
\text { River water rights, to feed horticulture, fruit } \\
\text { culture, maize and medicinal plant } \\
\text { cultivation in La Pintana, Santiago }\end{array}$ \\
\hline Municipality & Mexico & 2004 & $\begin{array}{l}\text { Traditional cultivation promotion in the } \\
\text { chinampas of Mexico city. }\end{array}$ \\
\hline Municipality & Brazil & 1998 & $\begin{array}{l}\text { Green Belt Programme, with duck farming } \\
\text { in the fluvial islands of periurban Belen. } \\
\text { Fruit culture and horticulture promotion in } \\
\text { Caratateua and Mosqueiro, periurban Belen. }\end{array}$ \\
\hline Municipality & Brazil & 1999 & $\begin{array}{l}\text { Feed Prudente Programme, with technical } \\
\text { assistance, seeds distribution to the farmers } \\
\text { interested in cleaning idle urban plots in } \\
\text { Presidente Prudente city, S. Paulo state. }\end{array}$ \\
\hline
\end{tabular}

Source: [38].

\section{Conclusions}

The food crisis and the great recession evolved together. There is a continuing tension between inequality and democracy; this outcries for inclusiveness as millions are marginalised from the labour market [33, 37]. This paper fuels the ongoing debate about the return to poverty and scarcity, whereas presenting positive examples of strategies to overcome natural catastrophes of small and medium proportion associated to climate change. Gardens and periurban farms are spaces of water permeation that mitigate both floods and desertification. They produce oxygen and constitute greenery that absorbs excessive carbon, and thus they mitigate the greenhouse effect. Gardens are quite biodiverse and have good ecological benefits in support of pollination and the preservation of species. Their sustainability is not only ecological but also cultural and economic.

Urban agriculture is now part of the new food equation. Rapid urbanisation, the rising sea levels, the changing weather, the intensification of floods, as the food price surge of 2007/08, and the ongoing great recession drive millions to poverty and urge policies of integration of gardening and farming in city planning [41]. Current paper mainly focused the gardens of health, meaning, the medicinal flora grown in front and backyards, and in vacant plots, in ten Latin American cities. Garden biodiversity has proven considerable, ranging from ninety-seven (97) different taxa used for therapeutic purposes in Belen, Brazilian Amazon Region, to eighteen (18) in the desert Iquique city, in Northern Chile. 
Native and exotic species are important legacies for future generations that current economic uncertainties are turning into a good alternative to mitigate mild health problems, permitting the less-wealthy and unemployed people from urban households to decrease the cost of their medical bills. Research results from the 1998 surveys conducted in Belen found that one third of the residents of that Brazilian city produced fresh vegetables, fruits and medicinal plants [2]. The proportion is now higher and the expectation is that more municipalities engage in urban agriculture programmes [3, 4, 10, 13, 14, 18-20, 22, 30-32, 40]. The hope is that more research will be conducted by interested scholars, so that science might provide ways to cope with the current world crisis.

\section{References}

[1] Sage, C. Environment and Food. Routledge: Abingdon, 2011.

[2] Madaleno, I.M. Urban Agriculture in Belém, Brazil. Cities. 17(1) pp. 7377, 2000.

[3] Madaleno, I.M. Urban Agriculture in Brazil. A tale of two cities. Trialog. 65(2) pp. 24-27, 2000.

[4] Castro Henriques, J. Urban agriculture and resilience in Lisbon: The role of the municipal government. Urban Agriculture Magazine. 22 pp. 49-50, 2009.

[5] Madaleno, I.M. A Comparative Study of Medicinal Plant Cultivation and Uses in Six Latin American Cities. Advances in Environmental Biology. 5(2) pp. 307-314, 2011.

[6] IFOAM, Definition and Principles of Organic Agriculture, 2012. Available at: http://www.ifoam.org/growing_organic/definitions/doa /index.html and http://www.ifoam.org/about_ifoam/principles/index.html (Accessed date: 12 June 2013).

[7] Madaleno, I.M. Organic Cultivation and Use of Medicinal Plants in Latin America. Pharmacognosy Communications, 2(4) pp. 34-51, 2012.

[8] Madaleno, I.M. Plantas da Medicina Popular de São Luís, Brasil. Boletim do Museu Paraense Emílio Goeldi. Ciências Humanas, 6(2) pp. 273-286, 2011.

[9] Madaleno, I.M. and Delatorre-Herrera, J. Medicina popular de Iquique, Tarapacá. IDESIA, 31(1) pp. 67-78, 2013.

[10] Madaleno, I.M. and Montero, M.C. El Cultivo Urbano de Plantas Medicinales, su Comercialización y Usos Fitoterapéuticos en la Ciudad de Río Cuarto, Provincia de Córdoba, Argentina. Cuadernos Geográficos, 50(1) 63-85, 2012.

[11] WCED, Our Common Future (Brundtland Report). United Nations World Commission on Environment and Development and Oxford University Press: Oxford, 1987.

[12] Lessmann, O. and Rauschmayer, F. Re-conceptualizing sustainable development on the basis of the capability approach: A model and its difficulties. Journal of Human Development and Capabilities: A Multidisciplinary Journal for People-Centered Development, 14(1) pp. 95-114, 2013. 
[13] Larsen, K. and Barker-Reid. Adapting to Climate Change and Building Urban resilience in Australia. Urban Agriculture Magazine. 22 pp. 22-24, 2009.

[14] Dawley, S., Pike, A. and Tomaney, J. Towards the resilient region. Local Economy, 25(8) pp. 650-667, 2010.

[15] Walburn, D. Europe 2020. Local Economy, 25(8) pp. 699-702, 2010.

[16] Vitali, S., Glattfelder, J.B. and Battiston, S. The Network of Global Corporate Control. ETH Zurich, Zurich, 2011.

[17] Stroink, M. L. and Nelson, C. H. Aboriginal Health Learning in the Forest and Cultivated Gardens: Building a Nutritious and Sustainable Food System. Journal of Agromedicine, 14(2) pp. 263-269, 2009.

[18] Madaleno, I.M. Cultivating our Cities. Environmental Impact. Ed. C. A. Brebbia and T.-S. Chon. WitPress: Southampton, pp. 183-192, 2012.

[19] Madaleno, I.M. Traditional Medicinal Knowledge in Cuba. Island Sustainability. Ed. S. Favro and C.A. Brebbia, C.A. WitPress: Southampton. pp. 101-110, 2010.

[20] Madaleno, I.M. and Gurovich, A. "Urban Versus Rural” no Longer Matches Reality: endurance of an early public agro-residential development in peri-urban Santiago, Chile. Cities, 21(6) pp. 513-526, 2004.

[21] Vennetier, P. La vie agricole à Pointe Noire (Congo), Les Cahiers d'Outre Mer XIV, 53(14) pp. 60-84, 1961.

[22] Egziabher, A. G. Urban Farming, Cooperatives and the Urban Poor in Addis Ababa. Cities Feeding People. Ed. L.J.A. Mougeot. International Development Research Centre: Ottawa, pp. 85-104, 1994.

[23] Pederson, R.M. and Robertson, A. Food policies are essential for healthy cities. Urban Agriculture Magazine, 1(3) pp. 9-11, 2001.

[24] Osborn, D. Commentary: Building on Rio+20 to Spur Action for Sustainable Development. Environment: Science and Policy for Sustainable Development. 55(3) pp. 3-13, 2013.

[25] Madaleno, I.M. Estudo Etnogeográfico de Plantas Medicinais na América Latina. Alêtheia Editores, Lisboa, 2013. Available at: http://www.varzeadarainha.pt/?area=loja\&livro=estudo-etnogeograficode-plantas-medicinais-da-america-latina (accessed date: 10 July 2013).

[26] Davies, C. and Scurlock, J. Bringing town and country closer together: Community forests in North East England. Urban Agriculture Magazine, 13 pp. 38-40, 2004.

[27] Batala, E. and Tsitsoni, T. Street tree health assessment system: A tool for study of urban greenery. International Journal of Sustainable Development and Planning, 4(4) pp. 344-355, 2011.

[28] Herchenbach, M. Food and the City. Journal of Landscape Architecture. 7(2) pp. 89, 2012.

[29] de Wet, H., Nkwanyana, M.N., van Vuuren, S.F. Medicinal plants used for the treatment of diarrhoea in northern Maputaland, KwaZulu-Natal Province, South Africa. Journal of Ethnopharmacology, 130 pp. 284-289, 2010. 
[30] Turner, B., Henryks, J. and Pearson, D. Community gardens: sustainability, health and inclusion in the city. Local Environment: The International Journal of Justice and Sustainability, 16(6) pp. 489-492, 2011.

[31] Peduto, E. and Satdinova, D. The role of urban agriculture in building resilient cities: Examples of building resilient neighborhoods in London. Urban Agriculture Magazine. 22 pp. 34-36, 2009.

[32] Santandreu, A. Perazzoli, A.G. Terrile, R. Ponce, M. Urban agriculture in Montevideo and Rosário: A response to crisis or a stable component of the urban landscape? Urban Agriculture Magazine. 22 pp. 12-13, 2009.

[33] Krugman, P. End this Depression Now! W. W. Norton, New York, 2012.

[34] Madaleno, I.M. Medicinal Herbs Cultivation, Trade and Consumption in Colonia del Sacramento, Uruguay. Conference on International Research on Food Security, Natural Resources. Göttingen: Georg-August Universität Göttingen and University of Kassel-Witzenhausen, 2012. Available at: http://www.tropentag.de/abstracts/full/10.pdf (Access date: 12 June 2013)

[35] Ruiz, A. Conquista Espiritual hecha por los religiosos de la Compañía de Jesús, en las Provincias del Paraguay, Paraná, Uruguay y Tape. Imprenta del Reyno: Madrid, 1639.

[36] Acosta, José de Historia natural y moral de las Indias. Casa Juan de León, Sevilla, 1590.

[37] Stone, C.N. Who is Governed? Local citizens and the political order of cities. Theories of Urban Politics. Ed. J.S. Davies and D.L. Imbroschio. Sage: London, pp. 257-273, 2009.

[38] Madaleno, I.M. Cultivando nuestras ciudades, estrategia de gobernanza las plantas medicinales del jardín y sus usos en América Latina. Las ciudades y el sistema urbano. Reflexiones en tiempos de crisis. Ed. A.M. Carballada, D. Royé and J.I.V. Vázquez. Galicia: Universidad de Santiago de Compostela e Asociación de Geógrafos Españoles, pp. 179-188, 2012. Available at: http://www.cityfarmer.info/2012/08/14/cultivating-our-citiesa-governance-strategy-medicinal-plants-and-uses-in-latin-america/\#more32001 and available at:http://www.uib.es/ggu/actes/actas_urb_2012.pdf (access date: 10 July 2013)

[39] Alegre, J., Escudero, D. and Tesdell, O. Agricultural Business Associations in Urban and Periurban Areas in Lima, Peru. Urban Agriculture Magazine. 17 pp. 41-42, 2007.

[40] Blum, A. Strategic Alliances: the organic farmers' association of Uruguay. Urban Agriculture Magazine. 17 pp. 11-12, 2007.

[41] Morgan, K. Feeding the city: The challenge of urban food planning. International Planning Studies, 14(4) pp. 341-348, 2009. 